\title{
İkinci Konutların Sosyo-Kültürel Etkilerine Yönelik Yerel Halkın Tutumları: Yalova-Çınarcık Örneği ${ }^{1}$
}

\author{
Local Resident Attitudes Towards Socio-Cultural Effects of Second Homes: Case of Yalova-Çınarcık
}

\author{
Ayşe OKUYUCU*, Mehmet SOMUNCU** \\ *Yrd. Doç. Dr., Bilecik Şeyh Edebali Üniversitesi Fen-Edebiyat Fakültesi Coğrafya Bölümü, Gülümbe Yerleşkesi, 11230, Bilecik. \\ E-posta: ayse.okuyucu@bilecik.edu.tr \\ ORCID: 0000-0002-4415-6520 \\ ** Prof. Dr., Ankara Üniversitesi Dil ve Tarih Coğrafya Fakültesi Coğrafya Bölümü, 45/45-A 06100, Sıhhiye/Ankara. \\ E-posta: somuncu@ankara.edu.tr \\ ORCID: 0000-0001-8890-0537
}

MAKALE BILGILERI

Makale işlem bilgileri:

Gönderilme tarihi: 23 Şubat 2017

Düzeltme: 28 Nisan 2017

Düzeltme: 5 Haziran 2017

Kabul: 21 Temmuz 2017

Anahtar sözcükler: İkinci konutlar,

İkinci konut turizmi, Sosyo-kültürel etkiler, Çınarcık, Yalova.

\section{ARTICLE INFO}

Article history:

Submitted: 23 February 2017

Resubmitted: 28 April 2017

Resubmitted: 5 June 2017

Accepted: 21 July 2017

Key words: Second homes, Second home tourism, Socio-cultural impacts, Çinarcık, Yalova.

\begin{abstract}
ÖZ
Bu makale, turizmin sosyo-kültürel etkileri konusunda yerel halkın algılarını araştırmaktadır. Çalışma alanı olan Çınarcık ilçe merkezi Türkiye'nin Marmara kıyısında yer alan eski bir ikinci konut destinasyonudur. Burada 1960'lardan itibaren dar kıyı șeridinde apartman șeklinde ikinci konutlar gelișme göstermiștir. Araștırmada veriler yerel halka uygulanan anketler aracılığıyla toplanmıştır. Anketler, Temmuz 2015 ve Ağustos 2015 tarihlerinde kolayda örneklem yöntemi ile seçilen 372 yerel sakine uygulanmıştır. Anket sonuçlarına göre; ikinci konutların ilçede eğlence olanaklarının artması, gruplar arasında dostluklar kurulması, göçlerin artması gibi çeşitli olumlu sosyo-kültürel etkileri ön plana çıkmıştır. Ancak ilçedeki alkol kullanımı ve suç oranının artması, geleneksel yaşam biçiminin değişmesi ise başlıca kaygı duyulan negatif sosyo-kültürel etkilerdir. Sosyo-kültürel etkiler konusundaki algılamalar, demografik değișkenlere göre anlamlı farklılıklar göstermiștir. Yanıtlar Çınarcık'ta ikinci konutların sosyo-kültürel etkilerinin genel olarak tatmin edici düzeyde olmadığııı göstermektedir.
\end{abstract}

\begin{abstract}
This paper investigates perceptions of local people about socio-cultural impacts of tourism. The study area is located on eastern coast of Marmara Sea in Çınarcık district of Turkey that has been used as a popular second home destination for years.Second homes have been constructed in the form of apartments on the narrow coastal strip in this area since 1960s. The data were collected by conducting questionnaire surveys with local residents. Questionnaire surveys were conducted with a total of 372 local residents selected by convenience sampling during July 2015 and August 2015. Results revealed that establishment of seconds homes in the area have various positive socio-cultural effects such as increasing the entertainment opportunities in the districts, establishing friendships networks among the groups and increase in immigration. However, local residents are also concerned about various negative socio-cultural effects of second homes, like increase inalcohol usage, increase in crime rate in the city and changing traditional way of life. The perceptions about sociocultural effects have shown significant differences according to demographic variables used in the study. It has been found that the socio-cultural effects of second homes in Cinarcik are generally percieved dissatisfying.
\end{abstract}

\section{GíRiş}

Turizm ve turizm deneyimi oldukça karmaşık ve çeşitlidir. Bununla birlikte günümüz toplumları turizm kültürü ve altyapısından büyük oranda etkilenmiştir. Geleneksel olarak bir ya da daha

\footnotetext{
${ }^{1}$ Bu makale, Ankara Üniversitesi Sosyal Bilimler Enstitüsü bünyesinde, Prof. Dr. Mehmet Somuncu danışmanlığında Ayşe Okuyucu tarafından hazırlanmış olan doktora tezinden üretilmiştir.
}

fazla yere zaman içinde hareket ve tekrar eve dönüş turizmin temeli olarak görülmektedir. Turistik gezi bir süreç olarak görülür ve turistlerin aldıkları karar ile başlar (Aronsson 2004: 80). Diğer turizm deneyimlerinde olduğu gibi ikinci konutlar da çoğunlukla bir kaçış şekli olarak görülür. İkinci konutlara olan hareket; hızlı, ucuz, güvenli ve kolaydır. Günümüzde ikinci konutlar; günlük geziler, hafta sonları, kısa süreli tatiller, uzun sü- 
reli tatiller ve sezonluk göçler için kullanılmaktadır. Bu nedenle ikinci konutlara olan talep oldukça yükselmiştir. Talebin artmasında; toplumsal refahın artması, toplum içinde yaşlı nüfusun artması, teknolojik gelişmeler, ulaşım ile ilgili gelişmeler ve küreselleşme vb. gibi faktörler etkili olmuştur. Günümüzde özellikle emekli nüfusun artan sezonluk hareketleri, ikinci konut konusunu yeniden gündeme taşımıştır (Müller 2004: 387). Clout (1969), ikinci konutları; sahipleri tarafından yılın belirli dönemlerinde, kısa süreli olmak üzere, otel dışında tatil amaçlı kullanılan konut ve apartman daireleri olarak tanımlamıştır. İkinci konutların tanımlanması oldukça zor bir konu olmasına rağmen, bazı konularda mutabakata varılmıştır (Müller 2011: 137). Örneğin ikinci konutlar için temel olan husus; onların kısa ve uzun süreli boş zamanlarda kullanılmak üzere rekreasyon amaciyla inşa edilmiş konutlar olmalarıdır (Özgüç 1977: 79).

İkinci konutlar turizmin önemli bir parças1nı meydana getirmektedir. İkinci konut turizmi, turizmin tanımında yer alan birçok unsuru bünyesinde barındırmaktadır. Örneğin ikinci konut sahipleri diğer turizm türlerinde olduğu gibi her zamanki çevrelerinden uzaklaşmak için seyahat ederler. İkinci konutlara olan ziyaretler zorunlu ya da daimi değildir. Bu özellikler ikinci konutlar konusunun turizm alanyazında aktif hale gelmesini sağlamıştır (Pitkänen ve Vepsäläinen 2008: 2).

Turizmdeki gelişmelerle birlikte birçok yer çeşitli ekonomik fayda sağlamaktadır. Bununla birlikte ikinci konut sahipleri ev sahibi topluma yeni bir kaynak getirmelerine rağmen, alanyazın, ikinci konut nüfusunun, yerel toplumlarda ekonomik, sosyal ve kültürel çatışma ve uyuşmazlıklara yol açabildiğini öne sürmektedir (Rye 2011: 263). Bu nedenle, bu çalışmada Türkiye'de kıyı alanlarda ikinci konutların gelişmesinin daha iyi anlaşılmasını sağlamak ve ikinci konutların sosyo-kültürel etkilerini belirlemek amaçlanmıştır. Daha spesifik olarak; bu araştırmada hafta sonu zonunda yer alan Yalova ilinin Çınarcık ilçe merkezinde, ikinci konutların sosyo-kültürel etkilerinin belirlenmesi amaçlanmıştır. Bu bağlamda çalışmada "İkinci konut turizminin Çınarcık'taki başlıca sosyo-kültürel etkileri nelerdir?" ve
“Çınarcık'ta yerel halkın demografik özellikleri ikinci konutların sosyo-kültürel etki algılamasını nasıl farklılaşmaktadır" sorularına yanıt aranmıştır. Çalışma Türkiye'de hafta sonu zonunda yer alan ikinci konutların, sosyo-kültürel etkilerini ilk defa ele alması bakımından önem taşımaktadır. İkinci konutların sosyo-kültürel etkilerinin değerlendirilmesi çeşitli bakımlardan önem taşımaktadır. Örneğin yerel halkın diğer grup olan ikinci konut sahiplerine yönelik tutumları turizmin başarı ve başarısızlı̆̆ında ya da daha fazla ziyaretçi çekme ve destinasyondaki ziyaretçilerin korunmasında önemli bir faktördür. Bunun yanı sıra sosyo-kültürel etkilerinin tanımlanması ve ölçülmesi, ziyaretçi ve yerel halk arasındaki olası çatışmaların önlenmesi için etkili bir strateji yaratmada önemlidir. Bu aynı zamanda paydaşlar arasındaki yıkıcı farkların azalması ve ilişkilerin güçlenmesine yol açacaktır (Alhasanat ve Hyasat 2011). Bu faydalar ziyaretçilere yansıdığı takdirde yakın gelecekte ziyaretçi sayılarını arttıracaktır.

\section{TÜRKIYE'DE IKINCI KONUTLARIN GELIŞMESi}

Türkiye'de günümüzdeki anlamda ikinci konutların gelişmesi; sanayileşme, kentleşme, ulaşım olanaklarının gelişmesi, boş zamanın artması ve moda gibi unsurlar sonucu 1950'lerde meydana gelmiştir (Emekli 2014: 34). Yeşilköy, Florya, Küçük Çekmece, Kartal ve Pendik gibi birçok semt eskiden ikinci konut yerleşim alanı olarak kullanılmıştır (Özgüç 1977: 81). Türkiye'de ilk düzenli ikinci konut yerleşimi, 1950'li yıllarda İzmirÇeşme kıyılarında meydana gelmiştir. Dünya'da olduğu gibi Türkiye'de de ikinci konutların asıl gelişmesi 1960'lı yillardan itibaren turizm sektörünün ülke kalkınmasının en iyi araçlarından biri olarak değerlendirilmeye başlanması ile birlikte kıyı alanlarda artmıştır (Kılıçaslan 2006). Bu dönemde diş turizmden çok iç turizme yönelik küçük işletmeler gelişme göstermiştir. 1970 ve 1980'ler Türkiye'de ekonomik ve siyasal anlamda çalkantılı yıllar olmuştur. Bu dönemde kentlere olan göç ve kentleşme ile birlikte başta İstanbul, İzmit, Adapazarı ve İzmir olmak üzere büyük kentlerin yakın çevresinde ikinci konutların inşa edilmesine olan talep artmıştır. 
Türkiye'de ikinci konutlara ilişkin düzenli istatistiki veriler bulunmamaktadır. Turizm Bakanlığı'nın 1990 yılında kıyı illere yönelik olarak yapmış olduğu İkinci Konut Envanteri isimli çalışmasının sonuçlarına göre bu dönemde Türkiye'de toplam 102.400 ikinci konut bulunmaktaydı (Turizm Bakanlığı 1990: 6). İkinci konutlar gelişmeye başladıkları 1960'lı yılların başından itibaren özellikle Türkiye'nin başlıca büyük şehirleri olan İstanbul, Bursa, Kocaeli illeri çevresinde yoğunlaşmışlardır. Daha sonraki süreçlerde Ege ve Akdeniz'deki başlıca büyük nüfus merkezlerine uzak tatil destinasyonları etrafında gelişme göstermiştir (Şekil 1). Buna karşılık Karadeniz kıyılarında ikinci konutların gelişimi; iklim, ulaşım koşulları uygun olmaması ve çevresinde büyük kentlerin olmaması nedeni ile daha kısıtlı olmuştur. Ancak 1980-1990 yılları arasında yaylalara erişim olanaklarının artması ile birlikte özellikle Doğu Karadeniz Bölümü'nde ikinci konutların inşası artmaya başlamıştır (Somuncu vd. 2010: 115). Düzenli bir veri setine ulaşmak güç olmakla birlikte, Nüfus ve Vatandaşlık İşleri Genel Müdürlüğü tarafından hazırlanan sayısal verilere göre, Türkiye'de 2008 yılında, 546.454 ve
2013 yılında 559.934 yazlık-mevsimlik konut bulunmaktadir (NVI 2014).

\section{IKINCI KONUTLARIN SOSYO-KÜLTÜREL ETKILERI}

Son zamanlarda dünya turizminin gelişmesi üzerine olan alanyazın çoğunlukla turizmin ev sahibi toplum üzerine olan etkilerine odaklanmaktadır (Pitkänen ve Vepsäläinen 2008; Dykes ve Walmsley 2015). Çünkü turizmle ilgili kalkınmanın yarattığ de ev sahibi toplumlar etkilenmektedir (Chuang 2013: 152; Ursić vd. 2016). Turizmin etkilerini s1nıflandırmak için çok sayıda yol vardır. Bunlardan en yaygin olanı Mathieson ve Wall'ın (1982) sinıflandırmalarıdır. Bu sinıflandırmada turizmin destinasyon toplumları üzerindeki etkilerini olumlu ve olumsuz olmaları bakımından ele alınmaktadır. Ancak bu sınıflandırmanın mutlak olmadığı, turizm tipleri ve turizmin amaçlarına göre değişebileceği göz önünde tutulmalıdır. İkinci konutların bazı sosyo-kültürel faydaları arasında; el sanatları ve geleneksel kültürel aktivitelerin yeniden canlanması, yerel halkın sosyal ve kültürel yaşamının canlanması, alandaki kültürel ve estetik değerlerin turizmle birlikte koru-

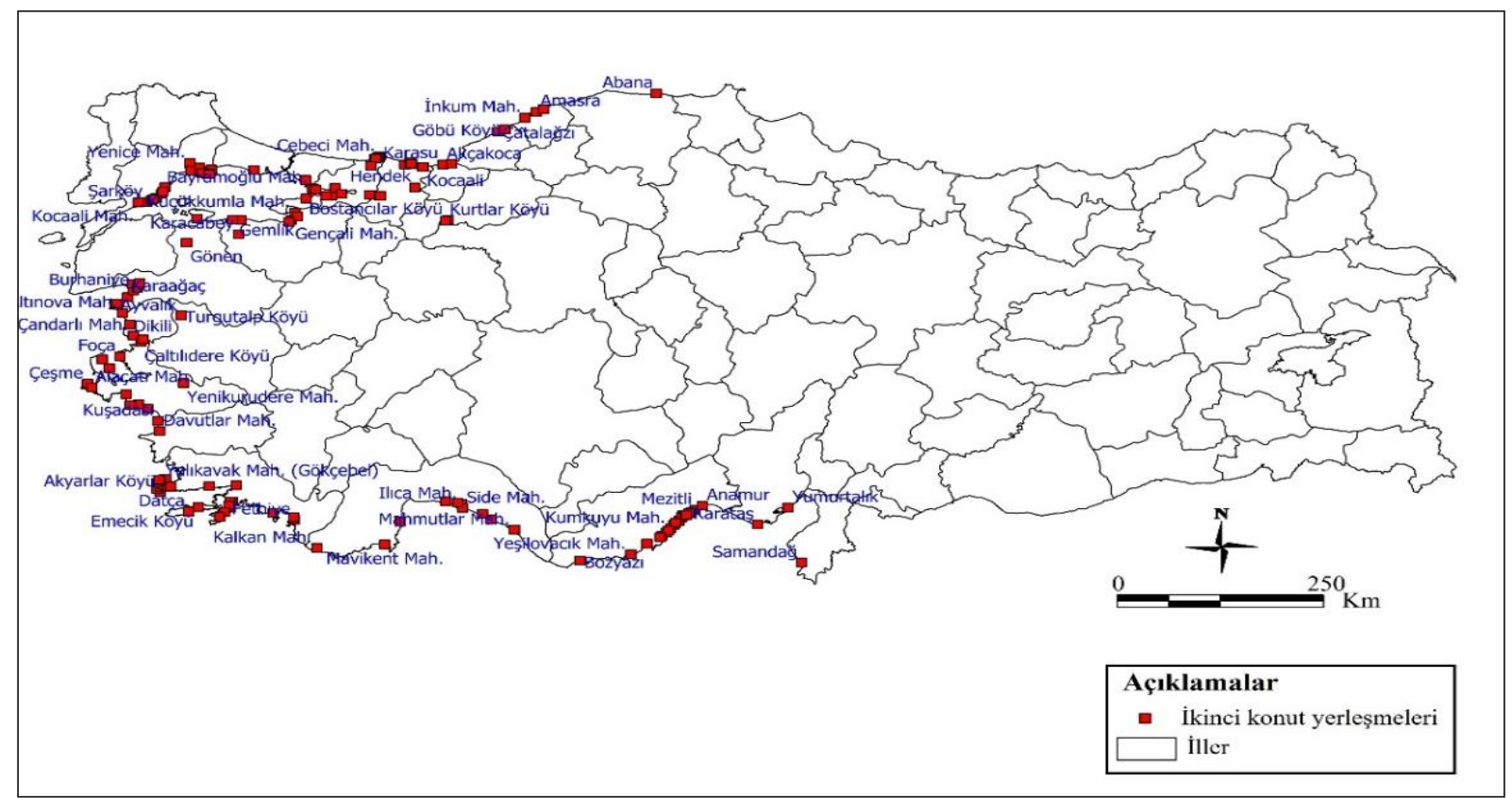

Tablo 2. Türkiye'de Kıyı Yerleşmeleride İkinci Konut Destinasyonları, 1999.

Kaynak: Turizm Bakanlığı (1990) verilerinden düzenlenmiştir. 
ma gerekliğinin artması gibi konulara dikkat çekilmektedir (Andereck vd. 2005; Sharpley 2006). Olumsuz sosyo-kültürel etkilere ise suç oranının artması, ahlaki değerlerin bozulması, aile yapısının değişmesi, geleneklerin metalaşması, kırsal toplum kompozisyonun bozulması ve toplulukların kentleşmesi örnek olarak verilebilir (Ap 1992; Marjavaara 2007; Farstad ve Rye 2013; Salazar ve Zhang 2013).

Günümüzde her aktivite gibi ikinci konutlar da sosyal, kültürel, çevresel ve ekonomik sonuçlarının sürdürülebilirliği bakımından tartışılmaktadır. Şüphesiz destinasyondaki sosyo-kültürel değişim sadece turizm vasıtası ile olmamaktadır. Bu değişim üzerinde aynı zamanda küreselleşme ve uluslararası medya da etkili olmaktadır (Hashimoto 2002: 212). İkinci konutların sosyo-kültürel etkileri çoğunlukla ekonomik nedenlere bağımlıdır. Her zararlı sosyo-kültürel etki, olumsuz bir ekonomik etki ile yakından ilişkilidir. Sosyokültürel etkiler çoğunlukla göze çarpmayan üstü kapalı etkilerdir ve bu etkileri ölçmek oldukça güçtür (Wang 2006: 25). Bu nedenle turizmin sosyo-kültürel etkilerinde ana araştırma odağı; turistlerden ziyade destinasyonda daimi olarak ikamet eden yerel halktır (Hall ve Page 2006: 196). Bundan hareketle, çalışmada turizmin aktüel etkilerinden ziyade, bölgede yaşayan yerel halkın turizm algıları ölçülmüştür.

Türkiye'de ikinci konutlara yönelik araştırmalar özellikle 1990'ların ortalarından itibaren, ikinci konutların doğal çevre üzerindeki etkilerine yönelik konularda olmuştur (Sabancı 1995; Dal ve Baysan 2007; Bakırcı 2007). Türkiye'de ikinci konutlarla ilgili olarak yapılan araştırmalarda, alanyazında dikkat çeken bir diğer konu da ikinci konutların turizm amaçlı kullanımına yönelik araştırmalardır (Kısa 1998; Manisa 2007; Kozak ve Duman 2011; Gökdeniz 2014; Özsoy 2015). Buna karşılık, ikinci konutların sosyo-kültürel etkileri konusundaki araştırmalar Türkiye'de oldukça azdır (Baltacı 2011).

\section{YÖNTEM}

Bu bölümde araştırmada kullanılan veri toplama araçları, araştırma evreni ve örneklemi ve son olarak araştırmada anketlerden elde edilen ve- rilerin analiz edilmesinde kullanılan yöntemler açıklanmaktadır.

\section{Veri Toplama Aracı}

Araştırma, nicel yöntem perspektifine göre yürütülmüştür. Veri toplamada yerel halka, ikinci konutların sosyo-kültürel etkilerine ilişkin olarak hazırlanmış olan anket uygulanmıştır. Anket Andereck vd. (2005), Müller (1999), Wang (2006), Cottyn (2011) ve Salamin'e göre (2011) göre oluşturulmuştur. Araştırmada kullanılan ölçeğin güvenirliliği Cronbach Alpha güvenirlik katsayısı ile ölçülmüş ve Cronbach Alpha güvenirlik katsayısı 0,756 olarak bulunmuştur. Anket iki bölümden oluşmaktadır. Anketin ilk bölümünde demografik değişkenler yer almaktadır, ikinci bölümünde ise ikinci konutların, sosyo-kültürel yapıda meydana getirdikleri etkilerin belirlenmesine yönelik ifadeler bulunmaktadır. Ankette beşli Likert ölçeği kullanılmıştır. Bu doğrultuda hazırlanan anketler Temmuz 2015 ve Ağustos 2015 tarihlerinde kolayda örneklem yöntemi ile seçilen 372 yerel sakine uygulanmıştır.

\section{Araştırmanın Evreni ve Örneklemi}

Yalova iline bağlı olan Çınarcık ilçesi; Türkiye'nin en önemli metropollerine hafta sonu zonu mesafesinde yer almaktadır. Çınarcık İstanbul'a 172, Adapazarı'na 130, Bursa'ya 82 ve İzmit'e 88 kilometre mesafede bulunmaktadır. Araştırma evrenini Çınarcık ilçe merkezinin kıyı kesiminde, ikinci konutların yer aldığı mahalleler ve burada yaşayan yerel halk oluşturmaktadır. Örneklemi oluşturan mahalleler ise Çınarcık ilçe merkezindeki Karpuzdere, Harmanlar, Taşliman ve Çamlık olmak üzere toplam dört mahalledir. Çınarcık'ta belirlenmiş olan mahallelerde toplam nüfus 11.937'dir (TÜIKK 2014). Alandaki yerel halk için evren tespit edildikten sonra, örneklem hesaplanmıştır. Araştırma evreni 11.937'dir ve \%95 güven düzeyinde $n=372$ kişilik bir örneklemdir. Tabaklı örnekleme tekniğine göre, araştırma alanında yer alan yerel halk evrende var oldukları aynı oranda mahallelere göre temsil edilmiştir. Buna göre toplam nüfusunun $\% 41^{\prime}$ ini temsil eden Harmanlar Mahallesine 153, \%33'ünü temsil eden Taşliman Mahallesine 123, \%13'ünü 
temsil eden Çamlık Mahallesine ve Karpuzdere Mahallesi'ne 48'er adet anket uygulanmıştır. Çınarcık'ta ikinci konutların yoğun olması ve Çınarcık'ın başlıca büyük şehirlerin hinterlantında olması çalışma alanının belirlenmesinde ana motivasyon kaynakları olmuştur.

\section{Analizler}

Uygulanan anketlerden elde edilen veriler IBM SPSS Statistics 21.0 paket programı ile analiz edilmiştir. Yerel halkın genel özelliklerini belirlemek amacıyla sıklık ve oran değerleri kullanılmıştır. Yerel halkın; ikinci konutların sosyo-kültürel etkileri konusundaki algı ortalamaları, her bir ifadeye verilen 1-5 puan aralığındaki yanıtlara göre hesaplanmıştır. Sosyo-kültürel etkileri ölçeklerinin yapı geçerlilikleri keşfedici faktör analizi (KFA) ile gerçekleştirilmiştir. Uygulanan faktör analizi sonucunda oluşan boyutlara atfedilen ortalama önem puanları ile demografik özellik grupları arasında anlamlı farklar olup olmadığı$\mathrm{n}$ belirmek amacı ile ikili değişkenler için $\mathrm{t}$ testi, ikiden fazla değişkene sahip olan gruplar için tek yönlü varyans analizi (ANOVA) testi uygulanmiştır. Uygulanan Levene test istatistiğine göre grupların varyansları homojen olduğundan fark analizlerinde parametrik testler olan t-testi ve ANOVA kullanılmıştır. Fark analizleri sonucun-

Tablo 1. Yerel Halkın Demografik Bilgileri

\begin{tabular}{lcc}
\hline Değiskenler & $N$ & (\%) \\
\hline Cinsiyet & 219 & \\
Erkek & 153 & 58,9 \\
Kadın & & 41,1 \\
\hline Medeni durum & 132 & \\
Bekâr & 240 & 35,4 \\
Evli & & 64,5 \\
\hline Doğum yeri & 169 & \\
Çınarcık & 203 & 45,4 \\
Diğer & & 54,6 \\
\hline Iş kategorisi & 186 & \\
Turizm & 186 & 50,0 \\
Diğer & & 50,0 \\
\hline Yaş & 53 & 14,2 \\
18-24 & 139 & 37,4 \\
$25-44$ & 142 & 38,2 \\
$45-64$ & 38 & 10,2 \\
$\geq 65$ & & \\
\hline
\end{tabular}

da anlamlı farklılık belirlenen gruplarda, farklılığın hangi grup ya da gruplardan kaynaklandığını tespit etmek için ise Tukey testi uygulanmıştır.

\section{ARAŞTIRMANIN BULGULARI}

Araştırmanın bulgularında ilk olarak katılımc1ların kişisel özelliklerine ilişkin tanımlayıcı istatistik sonuçları yer almaktadır. Daha sonra güvenilirlik ve geçerlilik analizine yer verilmiştir. Son olarak katılımcıların ikinci konutların sosyo-kültürel etkileri konusundaki ölçek maddelerine atfettikleri önem derecesine göre oluşan ortalama değerler ve fark analizleri sonuçlarına yer verilmiştir.

\section{Yanıtlayıcıların Profilleri}

Ankete katılan yanıtlayıcıların $\% 58,9^{\prime}$ u erkeklerden, \%41,1'i kadınlardan oluşmaktadır. Katılımcların \%64,5'i evlidir ve $\% 45,4$ 'ünün doğum yeri Çınarcık'tır. Katılımcıların \%50'si turizmle ilgili işlerde çalıştığını belirtmiştir. Katılımcılar çoğunlukla 45-64 (\%38,2) ve 25-44 (\%37,4) yaş aralığındadır. Ailelerin aylık toplam geliri çoğunlukla 1000-2500 TL (\%53) aralığındadır. \%31,7 ile lise mezunları en büyük paya sahiptir. Katılımcıların Çınarcık'ta ikamet süresi ise en fazla \%25 ile 2130 yıl arasıdır (Tablo 1).

Tablo 1. Yerel Halkın Demografik Bilgileri (Devam)

\begin{tabular}{lrr}
\hline Değişkenler & $N$ & (\%) \\
\hline Ailenin aylık geliri (TL) & 197 & \\
$1000-2500$ & 148 & 53,0 \\
$2501-5000$ & 27 & 39,8 \\
$\geq 5001$ & & 7,3 \\
\hline Eğitim & 69 & \\
Illkokul (<8 yıl) & 58 & 18,5 \\
Ilköğretim (28 yıl) & 118 & 15,6 \\
Lise & 41 & 31,7 \\
Ön lisans & 86 & 11,0 \\
Lisans ve lisansüstü & & 23,1 \\
\hline Ikamet süresi (yıl) & 84 & \\
$1-10$ & 57 & 22,6 \\
$11-20$ & 93 & 15,3 \\
$21-30$ & 49 & 25,0 \\
$31-40$ & 89 & 13,2 \\
$\geq 41$ & & 23,9 \\
\hline
\end{tabular}




\section{Faktör Analizi}

Araştırmaya katılan yöre halkının turizmin sosyo-kültürel etkilerine yönelik tutumlarını belirleyebilmek için ölçekte yer alan 25 önermeye faktör analizi uygulanmıştır. Faktör analizinde öz değeri (eigen value) 1,00'ın üzerinde olan ve faktör yükü 0,30'dan büyük olan ifadeler değerlendirmeye alınmıştır. Böylece madde eleme süresince ölçekteki madde sayısı 25'ten 20 maddeye indirilmiştir. Sosyo-kültürel etki ölçeğine yapılan faktör analizi sonucunda üç faktör ortaya çıkmıştır. Bu faktörlere içerdikleri ifadeler dikkate alınarak isim verilmiştir. İlk faktör "olumlu sosyo-kültürel etkiler", ikinci faktör "aile ve toplum üzerindeki olumsuz etkiler" ve üçüncü faktör "günlük yaşam üzerindeki olumsuz etkiler" olarak adlandirılmıştır.

Faktör analizi sonucuna göre oluşan üç faktör toplam varyansın yüzde 44,231'ini açıklamakta- dır. Her bir faktörün Cronbach Alpha güvenirlik katsayıları ise tüm faktörlerde 0,60'ın üzerindedir. Ayrıca Keiser Meyer Olkin (KMO) değeri 0,730'dur ve Bartlett's Test of Sphericity anlamlı $(p=0,000)$ çıkmıştır. Buna göre veriler faktör analizi için uygundur (Tablo 2).

\section{Yerel Halkın İkinci Konutların Sosyo-Kültürel Etkileri Konusundaki Görüşleri}

Katılımcıların ikinci konutların sosyo-kültürel etkileri konusundaki ölçek maddelerine atfettikleri önem derecesine göre oluşan "ortalama" değerler Tablo 3'te verilmiştir. Yerel halkın ikinci konutların "olumlu sosyo-kültürel etkileri" faktörüne atfettikleri önem derecelerine göre ortalama değer $(\bar{X}=3,45)^{\prime}$ tir. "Aile ve toplum üzerindeki olumsuz etkiler" faktörü en yüksek ortalamaya sahip olan faktörüdür $(\bar{X}=3,86)$. İkinci konutların "Günlük yaşam üzerindeki olumsuz etkileri”

Tablo 2. Sosyo-Kültürel Etki Ölçeğine İlişkin Faktör Analizi Sonuçları

\begin{tabular}{|c|c|c|c|}
\hline Faktörler & F1 & F2 & F3 \\
\hline \multicolumn{4}{|l|}{ F1.Olumlu sosyo-kültürel etkiler } \\
\hline Kadınların işgücüne katılımı artmaktadır. & ,689 & & \\
\hline Toplumda yeni meslekler ortaya çıkmaktadır. &, 684 & & \\
\hline Eğlence ve turizm tesisleri artmaktadır. &, 603 & & \\
\hline Yerel halk ve yazlıkçılar arasında dostluklar kurulmaktadır. &, 591 & & \\
\hline Yerel halkın hayat standartları yükselmektedir. &, 589 & & \\
\hline Kültürel değiş tokuş için firsatlar artmaktadır. &, 569 & & \\
\hline Çınarcık’a işçi göçleri artmaktadır. &, 542 & & \\
\hline Kadınların toplum içindeki rolleri özgürleşmektedir. & ,455 & & \\
\hline Yerel kültürel hayat yeniden canlanmaktadır. & ,406 & & \\
\hline \multicolumn{4}{|l|}{ F2.Aile ve toplum üzerindeki olumsuz etkiler } \\
\hline Gençler aile yapısından uzaklaşmaktadır. & & ,825 & \\
\hline Geleneksel yaşam biçimi bozulmuştur. & & ,755 & \\
\hline Aile yapısında olumsuz değişiklikler artmıştır. & & ,749 & \\
\hline Alkol kullanımı artmıştir. & & ,682 & \\
\hline Suç oranı artmaktadır. & & ,664 & \\
\hline \multicolumn{4}{|l|}{ F3.Günlük yaşam üzerindeki olumsuz etkiler } \\
\hline \multicolumn{3}{|l|}{ Yerel halk yazlık sahiplerinin kullandığı tesislerden yararlanamamaktadır. } & ,792 \\
\hline \multicolumn{3}{|l|}{ Plaj vb. turistlerin kullandığı alanlara yerel halkın girişi kısıtlanmaktadır. } & ,787 \\
\hline \multicolumn{3}{|l|}{ Dini inanç ve davranışlar değişmekte ya da yerine getirilememektedir. } & ,645 \\
\hline \multicolumn{3}{|l|}{ Ulaşım vb. hizmetler turizm sezonu dışındaki dönemlerde aksamaktadır. } & ,568 \\
\hline Yerel halkın şivesi değişmektedir. & & &, 551 \\
\hline \multicolumn{3}{|l|}{ Yerel halk fiyatlardaki yükseliş nedeniyle bölgeden dışarıya göç etmektedir. } & ,516 \\
\hline Cronbach alpha & ,743 & ,806 & ,645 \\
\hline Özdeğerler & 3,708 & 2,830 & 2,308 \\
\hline Açıklanan varyans (\%) & 15,202 & 14,736 & 14,293 \\
\hline Toplam açıklanan varyans (\%) & 44,231 & & \\
\hline
\end{tabular}

Keiser Meyer Olkin (KMO) değeri:0.730; Bartlett's Test of Sphericity sonucu: 2217.841 ( $\mathrm{p}<0,001)$. 
faktörü en düşük alg1 puanına sahiptir $(\bar{X}=2,48)$ (Tablo 3).

\section{Farklıık Analizleri}

Veri analizi sonuçlarında destekleyici bir çerçeve sağlamak için, araştırmaya katılan yanıtlayıcıların karakteristiklerinin araştırılması önemlidir. Bu nedenle bu kısımda faktör analizi sonucunda elde edilen faktörler ile yerel halkın demografik karakteristikleri arasında anlamlı farklılıklar olup olmadı̆̆ı değerlendirilmiştir.

$\mathrm{T}$ testi sonuçlarına göre kadın ve erkek ziyaretçiler için faktörlere atfedilen önem dereceleri bakımından anlamlı bir farklılık yoktur ( $p>0,05)$. Medeni durum ve faktörler arasında karşılaştırma yapıldığında ise "günlük yaşam üzerindeki olumsuz etkiler" faktörüne evliler $(\bar{X}=2,64)$, bekârlara göre $(\bar{X}=2,39)$ daha fazla önem atfetmiştir ve aralarındaki fark istatistiksel olarak anlamlidir $\left(\mathrm{t}_{(370)}=2,344 ; \mathrm{p}<0,05\right)$, (Tablo 4). Katılımcıların doğum yeri ile faktörlere atfedilen önem dereceleri arasında anlamlı bir farklılık bulunamamıştır. Buna göre yerel halkın doğum yerinin Çınarcık olması ya da olmaması turizmin sosyo- kültürel etki algılamaları konusunda farklılaşmaya yol açmamaktadır.

Çeşitli çalışmalarda aile üyeleri turizmde çalışan ve çalışmayan yerel sakinler arasında algısal farklılıklar olabileceği belirtilmiştir. Kuvan ve Akan (2005) Belek örneğinde "ekonomik problemler, ekonomik faydalar ve pozitif sosyo-kültürel" etki faktörlerinde aile üyeleri turizmle ilgili işlerde çalışan ve çalışmayan gruplar arasında istatistiksel olarak anlamlı farklar tespit etmiştir. Uygulanan t testi sonuçlarına göre, araştırma kapsamında iş kategorisi ile "olumlu sosyokültürel etkiler" ve "aile ve toplum üzerindeki olumsuz etkiler" faktörleri arasında anlamlı farklılıklar tespit edilmiştir. Olumlu sosyo-kültürel etkiler faktörüne turizmle ilgili işlerde çalışan gruplar $(\bar{X}=3,55)$, turizmle ilgili işlerde çalışmayan gruplara göre $(\bar{X}=3,34)$ daha fazla önem atfetmişlerdir $\left(\mathrm{t}_{(356,153)}=-2,860 \mathrm{p}<0,01\right)$. "Aile ve toplum üzerindeki olumsuz etkiler" faktörü ise turizmle ilgili işlerde çalışan gruplarda $(\bar{X}=3,98)$, turizmle ilgili işlerde çalışmayan gruplara göre $(\bar{X}=3,74)$ daha olumsuz bulunmuştur $\left(\mathrm{t}_{(356,516)}\right.$ $=-2,550 \mathrm{p}<0,05)($ Tablo 4).

Tablo 3. Sosyo-Kültürel Etkilere İlişkin Yerel Halkın Görüşlerinin Ortalamaları

\begin{tabular}{|c|c|c|}
\hline Faktör ve ifadeler & Ortalama $(\bar{X})$ & Standart sapma (S.S.) \\
\hline F1.Olumlu sosyo-kültürel etkiler & 3,45 & 0,68951 \\
\hline Kadınların işgücüne katılımı artmaktadır. & 3,47 & 1,178 \\
\hline Toplumda yeni meslekler ortaya çıkmaktadır. & 3,42 & 1,124 \\
\hline Eğlence ve turizm tesisleri artmaktadır & 3,70 & 1,200 \\
\hline Yerel halk ve yazlıkçılar arasında dostluklar kurulmaktadır. & 3,91 & 1,199 \\
\hline Yerel halkın hayat standartları yükselmektedir. & 3,23 & 1,260 \\
\hline Kültürel değiş tokuş için firsatlar artmaktadır. & 3,31 & 1,186 \\
\hline Çınarcık’a işçi göçleri artmaktadır. & 3,99 & 1,190 \\
\hline Kadınların toplum içindeki rolleri özgürleşmektedir. & 3,33 & 1,170 \\
\hline Yerel kültürel hayat yeniden canlanmaktadır. & 2,67 & 1,334 \\
\hline F2. Aile ve toplum üzerindeki olumsuz etkiler & 3,86 & 0,90939 \\
\hline Gençler aile yapısından uzaklaşmaktadır. & 3,85 & 1,243 \\
\hline Geleneksel yaşam biçimi bozulmuştur. & 3,62 & 1,334 \\
\hline Aile yapısında olumsuz değişiklikler artmıştır. & 3,51 & 1,249 \\
\hline Alkol kullanımı artmıştır. & 4,22 & 1,067 \\
\hline Suç oranı artmaktadır. & 4,10 & 1,150 \\
\hline F3.Günlük yaşam üzerindeki olumsuz etkiler & 2,48 & 0,90516 \\
\hline Yerel halk yazlık sahiplerinin kullandığı tesislerden yararlanamamaktadır. & 2,26 & 1,336 \\
\hline Plaj vb. turistlerin kullandığı alanlara yerel halkın girişi kısıtlanmaktadır & 2,34 & 1,431 \\
\hline Dini inanç ve davranışlar değişmekte ya da yerine getirilememektedir. & 2,43 & 1,337 \\
\hline Ulaşım vb. hizmetler turizm sezonu dışındaki dönemlerde aksamaktadır. & 3,03 & 1,497 \\
\hline Yerel halkın şivesi değişmektedir. & 2,27 & 1,311 \\
\hline Yerel halk fiyatlardaki yükseliş nedeniyle bölgeden dışarıya göç etmektedir. & 2,55 & 1,374 \\
\hline
\end{tabular}

1: Kesinlikle Katılmıyorum 2: Katılmıyorum 3: Kararsızım 4: Katılıyorum 5: Kesinlikle Katılıyorum 
Tablo 4. Sosyo-Kültürel Faktörlerin Sosyo-Demografik Özelliklere Göre T Testi Sonuçları

\begin{tabular}{|c|c|c|c|c|c|}
\hline Cinsiyet & Kadın $(\bar{X})$ & $\operatorname{Erkek}(\bar{X})$ & $S d$ & t değeri & p değeri \\
\hline \multicolumn{6}{|l|}{ Faktörler } \\
\hline F1.Olumlu sosyo-kültürel etkiler & 3,50 & 3,40 & 370 & 1,410 & 0,0159 \\
\hline F2.Aile ve toplum üzerindeki olumsuz etkiler & 3,88 & 2,59 & 370 & 0,603 & 0,0547 \\
\hline F3.Günlük yaşam üzerindeki olumsuz etkiler & 2,59 & 2,41 & 370 & 1,768 & 0,078 \\
\hline $\begin{array}{l}\text { Medeni durum } \\
\text { Faktörler }\end{array}$ & Evli $(\bar{X})$ & $\operatorname{Bekar}(\bar{X})$ & & $t$ değeri & $p$ değeri \\
\hline F1.Olumlu sosyo-kültürel etkiler & 3,52 & 3,41 & 370 & 1,455 & 0,146 \\
\hline F2.Aile ve toplum üzerindeki olumsuz etkiler & 3,80 & 3,89 & 370 & 0,875 & 0,382 \\
\hline F3.Günlük yaşam üzerindeki olumsuz etkiler & 2,64 & 2,39 & 370 & 2,344 & $0,020^{*}$ \\
\hline Doğum Yeri & Çınarcık $(\bar{X})$ & Diğer $(\bar{X})$ & $S d$ & $t$ değeri & $p$ değeri \\
\hline F1.Olumlu sosyo-kültürel etkiler & 3,42 & 3,46 & 370 & 0,541 & 0,589 \\
\hline F2.Aile ve toplum üzerindeki olumsuz etkiler & 3,96 & 3,78 & 363,453 & 1,942 & 0,053 \\
\hline F3.Günlük yaşam üzerindeki olumsuz etkiler & 2,38 & 2,56 & 370 & $-1,791$ & 0,074 \\
\hline Iş kategorisi & $\begin{array}{r}\text { Turizmle } \\
\text { ilgili işler (X) }\end{array}$ & $\begin{array}{r}\text { Turizm dışı } \\
\text { işler (X) }\end{array}$ & $S d$ & t değeri & $p$ değeri \\
\hline F1.Olumlu sosyo-kültürel etkiler & 3,55 & 3,34 & 356,153 & $-2,860$ & $0,004 * *$ \\
\hline F2.Aile ve toplum üzerindeki olumsuz etkiler & 3,98 & 3,74 & 364,516 & $-2,550$ & $0,011^{*}$ \\
\hline F3.Günlük yaşam üzerindeki olumsuz etkiler & 2,40 & 2,56 & 370 & 1,544 & 0,123 \\
\hline
\end{tabular}

${ }^{* *} \mathrm{P} \leq 0,01 \quad{ }^{*} \mathrm{P} \leq 0,05$

Araştırma kapsamında uygulanan ANOVA testi sonuçları Tablo 5'te verilmiştir. King ve arkadaşları (1993) yaş grubu daha yüksek olan ev sahibi halkın turizme yönelik daha pozitif olduklarını belirtmişlerdir. Nitekim elde edilen bulgulara göre; yaş grupları değişkeni ile "aile ve toplum üzerindeki olumsuz etkiler" faktörü arasında istatistiksel olarak anlamlı bir farklılık bulunmuştur $\left(\mathrm{F}_{(7,791)}=3,368 ; \mathrm{p}<0,01\right)$. Tukey testi sonuçlarına göre 25-44 yaş grubundakiler "aile ve toplum üzerindeki olumsuz etkiler" faktörüne 18-24 yaş grubu ile 65 ve üzeri yaş grubuna göre daha fazla önem atfetmiştir. Bu durumda orta yaş grubundakiler, ikinci konut turizminin aile ve toplum üzerindeki etkileri konusunda daha fazla endişelidirler.

Ailenin aylık toplam geliri değişkeni ile "olumlu sosyo-kültürel etkiler" ve "aile ve toplum üzerindeki olumsuz etkileri" faktörleri arasında anlamlı bir farklılık bulunmuştur. Tukey testinden elde edilen sonuçlara göre 5000 TL ve üzeri gelire sahip olanlar hem 1000-2500 TL hem de 25015000 TL arasında gelire sahip olanlara nazaran "olumlu sosyo-kültürel etkiler" faktörüne daha az önem atfetmişlerdir. Buna göre daha yüksek gelir düzeyine sahip olan grupların, turizmin olumlu sosyo-kültürel etkilerine daha az inan- dıkları söylenebilir. "Aile ve toplum üzerindeki olumsuz etkiler" faktörüne ise 2501-5000 TL arasinda gelire sahip olan grupların $(\bar{X}=4,05), 1000$ 2500 TL arasında gelire sahip olan gruplara göre $(\bar{X}=3,73)$ daha fazla önem atfettikleri görülmüştür.

Eğitim düzeyi yüksek olanlar turizmin toplumsal etkileri konusunda daha yüksek bir farkındalığa sahiptirler. Bu nedenle turizmin olumsuz sosyo-kültürel etkileri konusunda daha yüksek bir algılamaya sahiptirler (Brunt ve Courtney 1999: 496). Eğitim düzeyine ilişkin ANOVA testi sonuçlarına göre, "aile ve toplum üzerindeki olumsuz etkiler" faktörü ve "günlük yaşam üzerindeki olumsuz etkiler" faktörüne göre anlamlı farklılık göstermektedir. Tukey testi sonuçlarına göre, ön lisans $(\bar{X}=4,12)$ ve lisans $(\bar{X}=4,03)$ düzeyinde eğitime sahip olanlar, ikinci konutların "aile ve toplum üzerindeki olumsuz etkileri" faktörüne ilkokul düzeyinde eğitime sahip olanlara göre $(\bar{X}=4,58)$ anlamlı bir şekilde daha fazla önem atfetmişlerdir. İkinci konutların "günlük yaşam üzerindeki olumsuz etkileri" faktörüne ise ön lisans mezunlarının ( $\bar{X}=2,89)$ ilkokul mezunlarına göre $(\bar{X}=2,41)$ daha fazla önem atfettikleri görülmüştür. Buna göre ikinci konutların, günlük yaşam üzerindeki olumsuz etkileri, dü- 
şük eğitim seviyesine sahip olan gruplarda daha az hissedilmektedir.

Destinasyonda ikamet süresi fazla olanların, turizmin aile ve toplum üzerindeki etkileri konusunda olumsuz algılamaları daha yüksektir (McGehee ve Andereck 2004: 136). Nitekim ANOVA testi sonuçlarına göre Çınarcık'ta ikamet süresi ile "aile ve toplum üzerindeki olumsuz etkiler" faktörü arasında istatistiksel olarak anlamlı bir farklılık bulunmuştur $(\mathrm{F} \quad(4,367)=3,677$; $\mathrm{p}<0,01)$. Tukey testi sonuçlarına göre, Çınarcık'ta 41 yıldan fazla süredir ikamet edenler $(\bar{X}=4,01)$, 1-10 yıldır ikamet edenlere $(\bar{X}=3,96)$ göre "aile ve toplum üzerindeki olumsuz etkiler" faktörüne daha fazla önem atfetmişlerdir (Tablo 5).

\section{SONUÇLAR VE DEĞERLENDIRME}

Çalışmanın başlıca amacı, Çınarcık' taki yerel halkın turizmin sosyo-kültürel etkilerine yönelik algılarını araştırmak ve demografik değişkenlere göre gösterdiği farkları değerlendirmektedir.
Faktör analizinden elde edilen sonuçlara göre Çınarcık'ta ikinci konutların sosyo-kültürel etkilerine ilişkin üç faktörlü bir yapı ortaya çıkmıştır. İlk faktör ikinci konutların "olumlu sosyo-kültürel etkileri", ikinci faktör "aile ve toplum üzerindeki olumsuz etkileri" ve üçüncü faktör "günlük yaşam üzerindeki olumsuz etkiler" faktörüdür. İkinci konutların olumlu sosyo-kültürel etkileri faktörüne ilişkin alg1 ortalaması 3,45'tir. Yerel halk "olumlu sosyo-kültürel etkiler" faktöründe en fazla; Çınarcık'a olan göçlerin artması ifadesine katılım göstermişlerdir. İkinci konutların "aile yaşamı üzerinde yol açtığı olumsuz etkiler" faktöründe ise en olumsuz olarak gençler üzerindeki etkileri belirtmişlerdir. Daha sonra geleneksel yaşam biçimi ve aile yaşamında meydana gelen değişimleri belirtmişlerdir. İkinci konutların "günlük yaşam üzerindeki etkileri" faktörüne ise katılım ortalaması düşük çıkmıştır $(X=2,48)$. Yerel halk ikinci konutların yarattığ 1 gelirden dolayı günlük yaşam üzerindeki olumsuz etkileri tolere etmektedir.

Tablo 5. Sosyo-Kültürel Faktörlerin Sosyo-Demografik Özelliklere Göre One-Way ANOVA Sonuçları

\begin{tabular}{|c|c|c|c|}
\hline Sosyo-demografik değişkenler & $\begin{array}{c}\text { F1.Olumlu } \\
\text { sosyo-kültürel etkiler }\end{array}$ & $\begin{array}{l}\text { F2. Aile ve toplum üzerindeki } \\
\text { olumsuz etkiler }\end{array}$ & $\begin{array}{r}\text { F3. Günlük yaşam } \\
\text { üzerindeki olumsuz etkiler }\end{array}$ \\
\hline \multirow[t]{2}{*}{ Yaş } & $F=, 407$ & $F=7,791$ & $F=1,151$ \\
\hline & $p=, 748$ & $\mathrm{p}=, 000^{* *}$ & $p=, 328$ \\
\hline $18-24$ & 3,53 & 3,61 & 2,58 \\
\hline 25-44 & 3,45 & 4,05 & 2,54 \\
\hline $45-64$ & 3,43 & 3,90 & 2,41 \\
\hline$\geq 65$ & 3,37 & 3,36 & 2,31 \\
\hline \multirow[t]{2}{*}{ Ailenin aylık geliri } & $F=3,828$ & $F=5,436$ & $F=1,701$ \\
\hline & $p=, 023^{*}$ & $p=, 005^{* *}$ & $\mathrm{p}=, 184$ \\
\hline 1000-2500 TL & 3,46 & 3,73 & 2,40 \\
\hline 2501-5000 TL & 3,49 & 4,05 & 2,56 \\
\hline$\geq 5001+\mathrm{TL}$ & 3,10 & 3,78 & 2,59 \\
\hline \multirow[t]{2}{*}{ Eğitim } & $F=, 777$ & $F=4,009$ & $F=4,406$ \\
\hline & $p=, 541$ & $\mathrm{p}=, 003^{* *}$ & $\mathrm{p}=, 002 * *$ \\
\hline İlkokul (< 8 yıl) & 3,33 & 3,58 & 2,41 \\
\hline Illköğretim ( $\geq 8 y ı l)$ & 3,53 & 3,99 & 2,49 \\
\hline Lise & 3,49 & 3,75 & 2,27 \\
\hline Ön lisans & 3,45 & 4,12 & 2,89 \\
\hline Lisans ve üzeri & 3,42 & 4,03 & 2,61 \\
\hline \multirow[t]{2}{*}{ Ikamet süresi } & $F=1,043$ & $F=3,677$ & $F=2,208$ \\
\hline & $p=, 385$ & $p=, 006^{* *}$ & $p=, 068$ \\
\hline $1-10 \mathrm{yıl}$ & 3,35 & 3,96 & 2,64 \\
\hline $11-20 \mathrm{yıl}$ & 3,55 & 3,96 & 2,53 \\
\hline 21-30 yıl & 3,41 & 3,56 & 2,50 \\
\hline $31-40$ & 3,52 & 3,87 & 2,49 \\
\hline$\geq 41$ & 3,47 & 4,01 & 2,25 \\
\hline
\end{tabular}

**P $\leq 0,01 \quad * \mathrm{P} \leq 0,05$ 
T-testi sonuçlarına göre evli olanlar, turizmin günlük yaşam üzerindeki olumsuz etkilerini bekârlara göre daha fazla önemsemektedir. ANOVA sonuçlarına göre ise eğitim düzeyi yüksek olanlar, turizmin günlük yaşam üzerinde olumsuz etkilere yol açtığı konusuna daha fazla katılmışlardır. Turizmle ilgili işlerde çalışanlar, turizmin sosyo-kültürel etkilerini daha olumlu algılamışlardır. Ancak diğer yandan yüksek gelir grubuna sahip olan gruplar ise turizmin sosyokültürel etkilerini daha olumsuz görmüşlerdir. Turizmin "aile ve toplum üzerindeki olumsuz etkileri" ise turizmle ilgili işlerde çalışanlar tarafından daha fazla hissedilmektedir.

Çınarcık'ta 1960'lı yıllardan itibaren ikinci konutlar gelişmeye başlamıştır. Çınarcık başta İstanbul olmak üzere, İzmit, Adapazarı, Bursa gibi Türkiye'nin önemli büyük şehirlerinin hinterlandında yer almaktadır. Başta balıkçılık ve odunculukla geçimini sağlayan yerel halk, ikinci konutların gelişmesine bağlı olarak turizmle ilgili hizmet sektörlerinde çalışmaya başlamıştır. İkinci konutlar ilçede kentleşme hızını arttırırken primer sektörlerin hızla yok olmasına neden olmuştur. Bu değişim halkın sosyal ve kültürel öğelerinin de değişmesine yol açmıştır.

1990'1 y yllardan başlarından itibaren Türkiye'de, Ege ve Akdeniz'de yeni tatil destinasyonlarının gelişmesi, otel sektörünün gelişmesi, tatil anlayışının değişmesi, tatil olanaklarının ucuzlaması ve Ege ve Akdeniz gibi uzak destinasyonlara hava ve diğer ulaşım olanaklarının artması ile birlikte ikinci konutlara olan talep düşmeye başlamıştır. Bu nedenle Çınarcık da destinasyon olarak bu dönemde düşüş evresine girmiştir. Zaman içinde turizme bağlı olarak primer sektörlerden kopan yerel halk, geleneksel yaşam biçimini unutmuştur. İlçede hala ikinci konutlara bağlı olarak turizm faaliyetleri sürmektedir. Ancak 1999 Marmara Depremi'nden sonra konut fiyatları iyice düşmüş ve varlıklı yazlıkçılar konutlarını düşük fiyatlarla satarak güneyde daha moda destinasyonlara yönelmişledir. Böylece ilçedeki ikinci konutlar İstanbul, Bursa, Adapazarı, İzmit gibi büyük şehirlerde düşük ücretle çalışan aileler tarafından satın alınmıştır. Yerel halk yeni ikinci konut sahiplerinin getirilerinden ekonomik olarak tatminsizdir. Bu da onların sosyo-kültürel etkiler konusundaki algılamalarının negatif yönde ilerlemesine yol açmaktadır. Çevresinde Türkiye'nin önemli turist gönderen illeri bulunan Çınarcık'ta farklı turizm olanaklarına olan yatırımlar arttırılırsa, buraya olan talebin yüksek olması muhtemeldir. Bu durum eğitim, refah, kültürel aktiviteler vb. gibi sosyo-kültürel anlamda gelişmelere de yol açabilir. Bu nedenle sosyo-kültürel iyileşme için öncelikle alandaki turizm gelirlerinin arttırılmasına yönelik tedbirlerin alınması gereklidir.

\section{KAYNAKÇA}

Alhasanat, S.A. ve Hyasat, A.S. (2011). Sociocultural Impacts of Tourism on the Local Community in Petra, Jordan, Jordan Journal of Social Sciences, 4 (1): 114-158.

Andereck, K.L., Valentine, K.M.; Knopf, R.C. ve Vogt, C.A. (2005). Residents Perceptions of Community Tourism Impacts, Annals of Tourism Research, 32 (4): 1056-1076.

Ap, J. (1992). Residents Perceptions on Tourism Impacts, Annals of Tourism Research, 19 (4): 665-690.

Aronsson, L. (2004). Place Attachment of Vacation Resident: Between Tourists and Permanenet Residents. İçinde C.M. Hall and D. K. Müller, (Editors) Tourism, Mobility and Second Homes Between Elite Landscape and Common Ground (p. 75-86). Clevedon: Channel View Publications.

Bakırcı, S. (2007). Yabancıların İkinci Konut Talebinin Fiziksel Çevreye Etkisi: Dalyan Örneği. (Basılmamış Yüksek Lisans Tezi). Ankara: Gazi Üniversitesi Fen Bilimleri Enstitüsü.

Baltac1, F. (2011). İkinci Konut Turizmi Kapsamında Alanya'da Konut Edinen Yabanciların Kentin Sosyal, Kültürel ve Ekonomik Yapısına Etkileri (Basılmamış Yüksek Lisans Tezi). Balıkesir: Balıkesir Üniversitesi Sosyal Bilimler Enstitüsü.

Brunt, P. ve Courtney, P. (1999). Host Perceptions of Sociocultural Impacts, Annals of Tourism Research, 26 (3): 493-515.

Chuang, S.T. (2013). Resident Attidudes Toward Rural Tourism in Taiwan: A Compat-rative Viewpoint, International Journal of Tourism Research, 15: 152-170.

Clout, H.D. (1969). Second Homes in France, Journal of the Town Planning Institute, 55: 440-443.

Cottyn, I. (2011). The Spatial and Socio Cultural Impacts of Second Home Development A Case Study on Franschhoek South Africa (Unpublished Master Thesis). Netherlands: Utrecht University International Development Studies.

Dal, N. ve Baysan, S. (2007). Kuşadası'nda Kıyı Kullanımı ve Turizmin Mekânsal Etkileri Konusunda Yerel Halkın Tutumları, Ege Coğrafya Dergisi, 16: 69-85.

Dykes, S. ve Walmsley, A. (2015). The Reluctant Tourist? An Exploration of Second Home Owners' Perceptions of Their Inpcatson North Cornwall, UK, European Journal of Tourism, Hospitality and Recreation, 6 (2): 95-116. 
Emekli, G. (2014). İkinci Konut Kavramı Açısından Turizm Coğrafyasının Önemi ve Türkiye'de İkinci Konutların Gelişimi, Ege Coğrafya Dergisi, 23 (1): 25-42.

Farstad, M. ve Rye, J.F. (2013). Second Home Owners, Locals and Their Perspectives on Rural Development, Journal of Rural Studies, 30: 41-51.

Gökdeniz, A. (2014). Ev Turizmi Ayvalık ve Danimarka Navasol Örnekleri. Ankara: Detay Yayıncilık.

Hall, M. ve Page, S.J. (2006). The Geography of Tourism and Recreation Environment, Place and Space. Londra ve New York: Routledge.

Hashimoto, A. (2002). Tourism and Sociocultural Development Issues. İçinde; R. Sharpley and D. J. Telfer (Editors) Tourism and Development (p. 202-230). Great Britain: Channel View Publications.

Kılıçaslan, Ç. (2006). İkinci Konutların Deniz Kıyılarına Etkisi, Süleyman Demirel Üniv. Orman Fakültesi Dergisi, A (1): 147-156.

Kısa, P. (1998). İkincil Konut Mimarlığında Cephe, Kütle ve Dış Mekân Oluşumu (Bodrum-Antalya Arası Kıyı Yerleşmeleri) (Basılmamış Yüksek Lisans Tezi). Edirne: Trakya Üniversitesi Fen Bilimleri Enstitüsü.

King, B., Pizam, A. ve Milman, A. (1993). Social Impacts of Tourism: Host Perceptions, Annals of Tourism Research, 20 (4): 650-665.

Kozak, M. ve Duman, T. (2011). İkinci Konutların Turizm Sektörüne Kazandırılması: Muğla İli Datça İlçesi Örneği, Doğuş Üniversitesi Dergisi, 12 (2): 226-242.

Kuvan, Y. ve Akan, P. (2005). Residents Attitudes Toward General and Forest-related Impacts of Tourism: The Case of Belek, Antalya, Tourism Management, 26 (5): 691-706.

Manisa, K. (2007). İkincil Konutların Turizm Sektöründe Yeniden Kullanılabilmesine İlişkin Bir Model Önerisi ( $B a-$ sılmamıs Doktora Tezi). İstanbul: Yıldız Teknik Üniversitesi Fen Bilimleri Enstitüsü.

Marjavaara, R. (2007). The Displacement Myth: Second Home Tourism in the Stockholm Archipelago, Tourism Geographies: An International Journal of Tourism Space, Place and Environment, 9 (3): 296-317.

Mathieson, A. ve Wall, G. (1982). Tourism: Economic, Physical and Social Impacts. Londra: Longman.

McGehee, N.G. ve Andereck, K.L. (2004). Factors Predicting Rural Residents' Support of Tourism, Journal of Travel Study, 43: 131-140.

Müller, D.K. (1999) German Second Home Owners in The Swedish Countryside: On The Internationalization of the Leisure Space (Basılmamıs Doktora Tezi). Sweden: Umeå University Department of Social and Economic Geography.

Müller, D.K. (2004). Mobility, Tourism and Second Homes. İçinde; M. Hall and D. K. Müller (Editors) Tourism, Mobility and Second Homes Between Elite Landscape and
Common Ground (p. 387-398). Clevedon: Channel View Publications.

Müller, D.K. (2011). Second Homes in Rural Areas: Reflections on a Troubled History, Norsk Geografisk TidsskriftNorwegian Journal of Geography, 65 (3): 137-143.

NVI (2014). http://www.nvi.gov.tr/NVI.html, Erişim tarihi: 29 Ekim 2015.

Özgüç, N. (1977). Tatil Evleri, İstanbul Teknik Üniversitesi Mimarlık Fakültesi Şehircilik Enstitüsü Dergisi, 14: 69-92.

Özsoy, T. (2015). Türkiye'de İkincil Konutların Turizmin Pazarlamasında Kullanımı, Kafkas Üniversitesi İktisadi ve İdari Bilimler Fakültesi Dergisi, 6 (10): 01-18.

Pitkänen, K. ve Vepsäläinen, M. (2008). Foreseeing the Future of Second Home Tourism: The Case of Finnish Media and Policy Discourse, Scandinavian Journal of Hospitality and Tourism, 8 (19): 1-24.

Rye, J.F. (2011). Conflicts and Contestations, Rural Populations Perspectives on the Second Homes Phenomenon, Journal of Rural Studies, 27: 263-274.

Sabancı, S. (1995). Ekolojik Açıdan Turizm Yerleşimlerinin K1y1 Kullanımına Etkisi (İkinci Konut Olgusu-Silivri Örneği) (Basılmamış Yüksek Lisans Tezi). İstanbul: Mimar Sinan Güzel Sanatlar Üniversitesi Fen Bilimleri Enstitüsü.

Salamin, F. (2011). Integration of Second Homeowners: An Alternative Solution to the Second Home Problems in Brione Sopra Minusio (Basılmamış Yüksek Lisans Tezi). Italya: Università della Svizzera Italiana.

Salazar, N.B. ve Zhang, Y. (2013). Seasonal Lifestyle Tourism: The Case of Chinese Elites, Annals of Tourism Research, 43: 81-99.

Sharpley, R. (2006). Travel and Tourism. Londra: Sage Publications.

Somuncu, M., Akpınar, N., Kurum, E., Çubuk Kaya, N. ve Özelçi Eceral, T. (2010). Gümüşhane İli Yaylalarındaki Arazi Kullanımı ve İşlev Değişiminin Değerlendirilmesi: Kazıkbeli ve Alistire Yaylaları Örneği, Ankara Üniversitesi Çevre Bilimleri Dergisi, 2 (2): 107-127.

Turizm Bakanlığ1 (1990). İkinci Konut Envanteri, 1989 (Rapor No: 1990/3). Ankara: Turizm Bakanlığı Yatırımlar Genel Müdürlüğü.

TÜIK (2014). https://biruni.tuik.gov.tr/adnksdagitapp/adnks.zul, Erişim tarihi: 17 Aralık 2015.

Ursić, S., Mišetić, R. ve Mišetić, A. (2016). How to Preserve Landscape Quality-Second Home Paradox, International Conference Green Urbanism, Procedia Environmental Sciences (101-111). Elsevier.

Wang, X. (2006). The Second Home Phenomenon in Haikou China (Basılmamış Yüksek Lisans Tezi). Canada: University of Waterloo, Planning Department. 


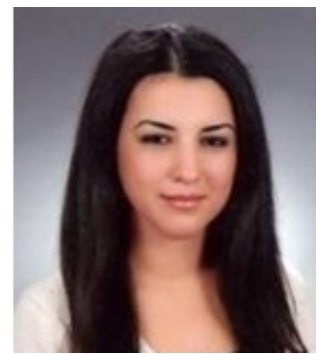

\section{Ayşe OKUYUCu}

Ankara Üniversitesi Dil ve Tarih-Coğrafya Fakültesi'nden (Coğrafya Bölümü'nden) mezun oldu (2008). Yüksek lisans derecesini Ankara Üniversitesi'nden Coğrafya Anabilim dalından (2011), doktora derecesini de Ankara Üniversitesi'nden Coğrafya Anabilim dalından aldı (2016). Bilecik Şeyh Edebali Üniversitesi'nde çalışmaya bașladı (2010). Halen Bilecik Şeyh EdebaIi Üniversitesi Fen-Edebiyat Fakültesi'nde görev yapmaktadır. Temel çalışma alanları Kültür ve Miras Turizmi, İkinci Konut Turizmi ve Turizm Coğrafyasıdır.

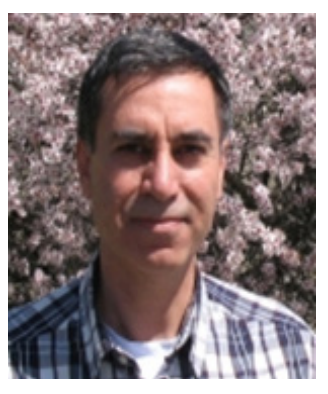

\section{Mehmet SOMUNCU}

Ankara Üniversitesi Dil ve Tarih-Coğrafya Fakültesi'nden (Fiziki Coğrafya ve Jeoloji Anabilim Dalından) mezun oldu (1984). Yüksek lisans derecesini Ankara Üniversitesi'nden Coğrafya Anabilim dalından (1987), ve doktora derecesini de Ankara Üniversitesi'nden Coğrafya Anabilim dalından aldı (1993). Yüksek lisans döneminde 1985-1987 yılları arasında TÜBiTAK Yapı Araştırma Enstitüsü'nde araştırmacı olarak görev yaptı. Ankara Üniversitesi'nde çalıșmaya başladı (1989). Doçentlik unvanını Beşeri ve İktisadi Coğrafya alanında aldı (2006). Profesörlüğe Ankara Üniversitesi'nde yükseltildi (2011). Halen Ankara Üniversitesi Dil ve Tarih-Coğrafya Fakültesi'nde görev yapmaktadır. Temel çaıışma alanları Turizm ve Rekreasyon, Kırsal Coğrafya, Çevre ve Sürdürülebilir Kalkınmadır. 